\title{
Hazard Analysis Critical Control Points (HACCP) Principle 2: Determine Critical Control Points (CCPs) 1
}

Ronald H. Schmidt and Debby L. Newslow ${ }^{2}$

Based upon the results of the hazard analysis, the HACCP team determines Critical Control Points (CCPs). Determination of CCPs involves a thorough examination of the processing steps listed on the flow diagram and on the Hazard Analysis Worksheet. In this determination, the HACCP team identifies the steps in the processing scheme where control of food hazards is applied for each product. There may be some debate among team members regarding these Control Points. It is important to remember that HACCP is a food safety system, not a food quality system. Thus, CCPs specifically deal with food safety issues, not food quality issues. According to the National Advisory Committee on Microbiological Criteria for Foods (NACMCF), CCPs can be differentiated from Control Points (CPs) as follows:

- A Control Point (CP) is any step at which biological, physical, or chemical factors can be controlled;

- A Critical Control Point (CCP) is any step at which factors can be controlled when this control is essential to prevent a food safety hazard, eliminate a food safety hazard, or reduce a food hazard to an acceptable level. 
- Approach A: This approach is used by some HACCP auditors in the regulatory and private sector. It dictates that a hazard deemed significant in the Hazard Analysis must be controlled at a CCP. It then follows that a hazard which is, in fact, managed by a prerequisite program is considered not "reasonably likely to occur" because of the prerequisite program.

- Approach B: In this approach, prevention and control of identified significant hazards can either be at a CCP or through rigorously applied prerequisite programs.

No set number of CCPs is required in HACCP. Rather, CCPs must be determined for each specific food processing and handling system and be appropriate to that specific system. Having too many CCPs could unnecessarily encumber and burden the implementation of the HACCP plan. Conversely, having too few CCPs could jeopardize food safety.

CCPs that involve subjective control measures (e.g., visual parameters, observations) rather than objective control measures (e.g., temperature, time) are difficult to implement and require more creativity with regard to CLs and monitoring procedures. For this reason, many HACCP plans now have fewer CCPs than they did historically, with the emphasis instead being placed on sound, well-conceived, and well-implemented Prerequisite Programs.

\section{A. CCP Decision Tree}

In a traditional HACCP application, the original or modified version of the NACMCF CCP decision tree or flow chart is used. Applying this decision tree involves asking a series of questions to determine whether a process step is a CCP. An example of a modified CCP decision tree is shown in Figure 1.

\section{B. CCP Determination}

An alternative procedure for $\mathrm{CCP}$ determination is to incorporate appropriate questions from the decision tree onto a form, as shown in Table 1. This format may be a little more useable and engaging for HACCP team members than the tree format. Each step from the flow diagram is listed in the first column and significant hazards from the hazard analysis are listed in the second column. The HACCP team responds to the questions listed in subsequent columns and ultimately identifies the CCP in the last column.

\section{CCP Determination Scenarios}

Some examples of CCP determination scenarios in different food industry segments are presented below.

\section{A. Low-Acid Canned Foods}

- Hazard: Biological (Clostridium botulinum)

- Control Measure: Thermal inactivation (temperature/time)

In this scenario, the retort or thermal processing step is clearly a CCP from which realistic, easily monitored CLs can be defined.

\section{B. Pasteurized Milk}

- Hazard: Biological (enteric pathogens, listed specifically)

- Control Measure: Thermal inactivation (temperature/time)

As in the previous example, the pasteurizer or thermal processing step is clearly a CCP from which realistic, easily monitored CLs can be defined.

\section{Cheddar Cheese}

- Hazard: Biological (Staphylococcus aureus: enterotoxin)

- Control Measure: Inhibition of growth by lactic acid production during fermentation

The fermentation step, where the starter microorganisms grow and produce lactic acid, can be identified as a CCP. However, the process of setting CLs and monitoring is not as clear as in the previous examples.

\section{Ground Beef}

- Hazard: Metal fragments 


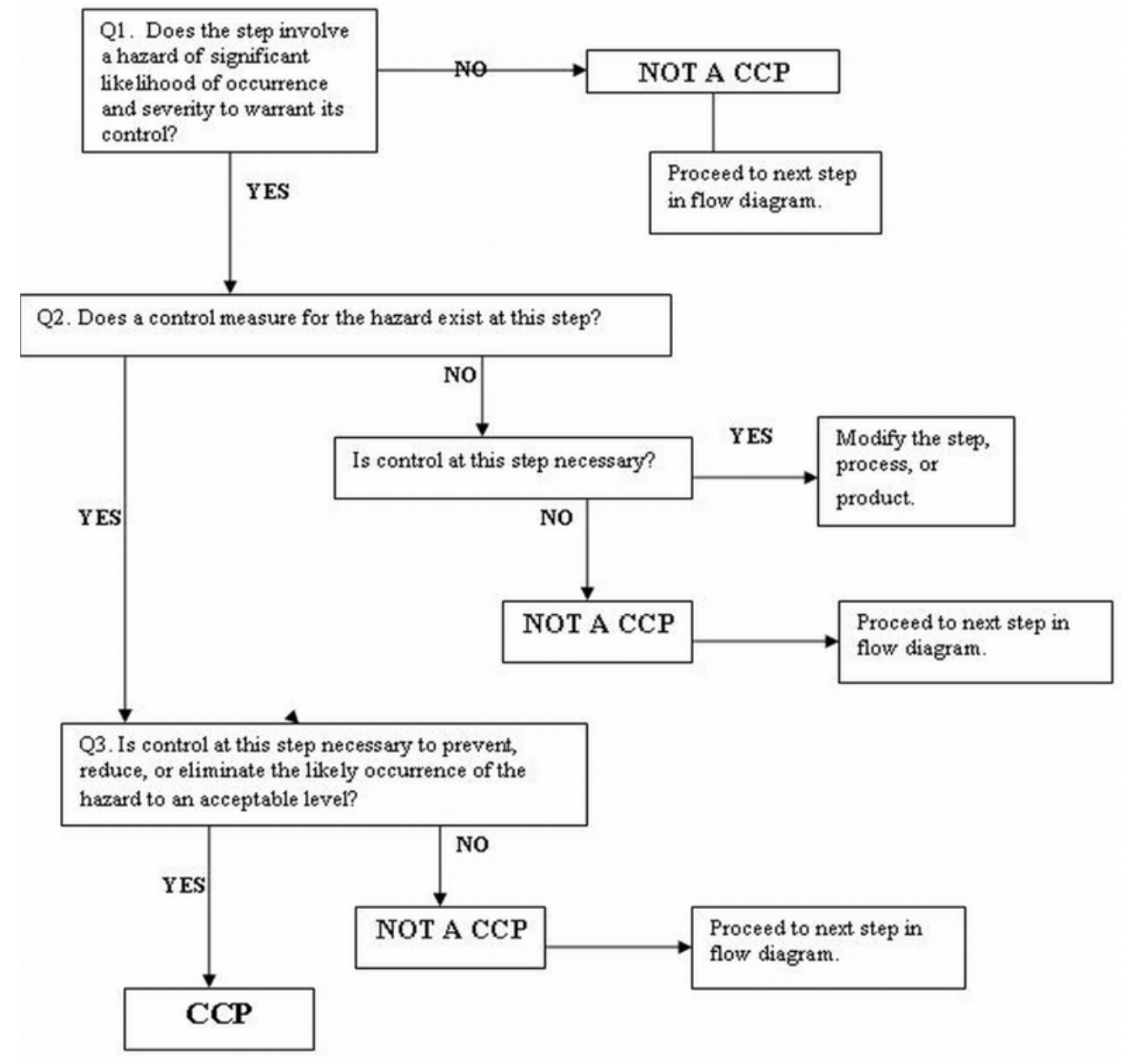

Figure 1. An Example of a Modified Critical Control Point (CCP) Decision Tree or Flow Chart

- Control Measures: Visual inspection, magnet after the grinder, metal detector after packaging

In this scenario, the team may be tempted to list three CCPs: one for each control measure. However, the CCP decision tree, if used properly, would lead the team to one CCP: the final metal detector after packaging. This is also an example of a situation where the team might determine that it is more appropriate and more practical to manage the hazard using prerequisite programs.

\section{E. Fresh Produce}

- Hazard: Biological (pathogens listed specifically)

- Control Measure: Inactivation using chemical sanitizer
The processing step whereby the produce is sprayed with a chemical sanitizer is the CCP. This $\mathrm{CCP}$ does provide the basis for realistic $\mathrm{CL}$ identification and monitoring.

\section{F. Packaged Fruit Juice}

- Hazard: Biological (enteric pathogens listed specifically)

- Control Measure: Cleaning filler; sanitizing filler (concentration/time)

In this scenario, while cleaning the filler is important to food safety, it would be difficult to implement as a CCP, as CL determination and monitoring would be difficult. Sanitizing the filler could be used as a CCP, as a CL could be determined and it could be monitored. However, the team would probably find it more appropriate to manage this 
function by implementing Sanitation Standard Operating Procedures (SSOPs).

\section{Categorizing and Recording CCPs}

In order to facilitate auditing and verification by the HACCP team or other auditors, it may be desirable to sequentially number the CCPs (e.g. CCP \#1, CCP \#2). Further, it may be helpful to classify CCPs according to whether the hazard is prevented (CCPp), reduced (CCPr), or eliminated (CCPe). It also may be useful to classify the CCPs by the type of hazard that is being controlled (e.g., CCP-B for biological hazards, CCP-C for chemical hazards, and CCP-P for physical hazards). It is further recommended that the CCPs be listed on the Flow Diagram to assist in review and verification activities. Since they provide the basis for subsequent HACCP principles and activities, CCPs must also be listed on a HACCP plan form, as shown in Table 2.

\section{Optimum Number of CCPs}

No set number of CCPs is required in a HACCP plan. In order for any plan to be effective, it is essential that the identified CCPs be appropriate for the specific food processing and handling system. Having too many CCPs may unnecessarily encumber and burden the implementation of the HACCP plan. CCPs that involve subjective control measures (e.g., visual parameters and observations) rather than objective control measures (e.g. temperature, time) are difficult to implement and require more creativity with regard to CLs and monitoring procedures. For this reason, many current HACCP plans put more emphasis on sound, well-conceived Prerequisite Programs and have fewer CCPs than they did historically.

\section{Summary}

CCP determination involves a thorough re-evaluation of the Hazard Analysis. Since CCPs provide the background for subsequent HACCP principles, it is important that those chosen are appropriate with regard to food safety control and realistic and practical with regard to implementing the HACCP plan. While it is important to put considerable thought into the decision process, this process should not be overly laborious and cumbersome.

\section{References}

Codex Alimentarius. (2003). Hazard analysis and critical control point (HACCP) system and guidelines for its application. ANNEX to Recommended International Code of Practice/General Principles of Food Hygiene. CAC/RCP 1-1969, Rev 4. FAO/WHO Codex Alimentarius Commission.

National Advisory Committee on Microbiological Criteria for Foods (NACMCF). (1998). Hazard analysis and critical control point principles and application guideline. Journal of Food Protection, 61, 762.

Food and Drug Administration Center for Food Safety and Applied Nutrition. (1995). Fish and fishery products. Code of Federal Regulations, Title 21, Part 123.

Food and Drug Administration Center for Food Safety and Applied Nutrition. (1995). Procedures for the safety and sanitary processing and importing of fish and fishery products. Final Rule, 18 Dec. 1995. Federal Register, 60, 65095-65202.

Food and Drug Administration Center for Food Safety and Applied Nutrition. (2001). Hazard analysis and critical control point (HACCP) systems. Code of Federal Regulations, Title 21, Part 120.

Food and Drug Administration Center for Food Safety and Applied Nutrition. (2001). Hazard analysis and critical control point (HAACP) (sic) procedures for the safe and sanitary processing and importing of juice. Final Rule, 19 Jan. 2001. Federal Register, 66, 6137-6202.

Food Safety and Inspection Service. (1996). Hazard analysis and critical control point (HACCP) systems. Code of Federal Regulations, Title 9, Part 417. 
Food Safety and Inspection Service. (1996).

Pathogen reduction; hazard analysis and critical

control point (HACCP) systems. Final Rule, 25 July

1996. Federal Register, 61, 38856-38906

Scott, V. N., and Stevenson, K. E. (2006).

HACCP: A systematic approach to food safety.

Washington, D.C.: Food Products Association.

Schmidt, R. H., and Newslow, D. L. (2007).

Hazard analysis critical control points (HACCP) Getting started, preliminary steps (FSHN0701).

Gainesville: Department of Food Science and Human

Nutrition, Florida Cooperative Extension

Service, Institute of Food and Agricultural Sciences, University of Florida. Retrieved July 24, 2007, from http://edis.ifas.ufl.edu/FS137

Schmidt, R. H., and Newslow, D. L. (2007).

Hazard analysis critical control points (HACCP) Prerequisite programs (FSHN0702). Gainesville:

Department of Food Science and Human Nutrition, Florida Cooperative Extension Service, Institute of Food and Agricultural Sciences, University of Florida. Retrieved July 24, 2007, from http://edis.ifas.ufl.edu/FS138

Schmidt, R. H., and Newslow, D. L. (2007).

Hazard analysis critical control points (HACCP) Principle 1: Conduct a Hazard Analysis

(FSHN0703). Gainesville: Department of Food

Science and Human Nutrition, Florida

Cooperative Extension Service, Institute of Food and

Agricultural Sciences, University of Florida.

Retrieved July 25, 2007, from

http://edis.ifas.ufl.edu/FS139 
Table 1. An Example of a Commonly Used Critical Control Point (CCP) Determination Form

\begin{tabular}{|c|c|c|c|c|c|c|}
\hline \multicolumn{7}{|c|}{$\begin{array}{l}\text { CCP Determination } \\
\text { (A critical control point is defined as a point, step or procedure at which control can be applied and a food safety } \\
\text { hazard can be prevented, eliminated, or reduced to acceptable levels) }\end{array}$} \\
\hline $\begin{array}{l}\text { PROCESS } \\
\text { STEP }\end{array}$ & $\begin{array}{l}\text { HAZARD(S) } \\
\text { Biological - B } \\
\text { Chemical - C } \\
\text { Physical - P } \\
\text { Hazard } \\
\text { Description }\end{array}$ & $\begin{array}{l}\text { Q1. Do } \\
\text { preventive } \\
\text { measures } \\
\text { exist for the } \\
\text { identified } \\
\text { hazard(s)? } \\
\text { *If no = not a } \\
\text { CCP. Identify } \\
\text { how and } \\
\text { where this } \\
\text { hazard will } \\
\text { be controlled. } \\
\text { * If yes = } \\
\text { move to next } \\
\text { question. }\end{array}$ & $\begin{array}{l}\text { Q2. Does this } \\
\text { step eliminate } \\
\text { or reduce the } \\
\text { likely } \\
\text { occurrence of } \\
\text { a hazard(s) to } \\
\text { an acceptable } \\
\text { level? } \\
\text { *If no = move } \\
\text { to the next } \\
\text { question. } \\
\text { *If yes = CCP. }\end{array}$ & $\begin{array}{l}\text { Q3. Could } \\
\text { contamination } \\
\text { with identified } \\
\text { hazard(s) occur } \\
\text { in excess of } \\
\text { acceptable } \\
\text { levels, or could } \\
\text { these increase } \\
\text { to unacceptable } \\
\text { levels? } \\
\text { *If no = not a } \\
\text { CCP. } \\
\text { *If yes = move to } \\
\text { the next } \\
\text { question. }\end{array}$ & $\begin{array}{l}\text { Q4. Will a } \\
\text { subsequent } \\
\text { step } \\
\text { eliminate } \\
\text { hazard(s) or } \\
\text { reduce the } \\
\text { likely } \\
\text { occurrence } \\
\text { to an } \\
\text { acceptable } \\
\text { level? } \\
\text { *If no = CCP. } \\
\text { *If yes = not } \\
\text { a CCP. }\end{array}$ & \#CCP \\
\hline \multicolumn{7}{|l|}{ DATE: } \\
\hline \multicolumn{7}{|c|}{ APPROVED BY: } \\
\hline
\end{tabular}

Table 2. An Example of a HACCP Plan Summary Form

\begin{tabular}{|c|c|c|c|c|c|c|c|c|c|}
\hline \multicolumn{10}{|c|}{ HACCP Plan Form } \\
\hline \multirow{2}{*}{$\begin{array}{l}\text { Critical } \\
\text { Control } \\
\text { Point } \\
\text { (CCP) }\end{array}$} & \multirow[t]{2}{*}{ Hazard(s) } & \multirow{2}{*}{$\begin{array}{l}\text { Critical } \\
\text { Limits } \\
\text { for Each } \\
\text { Control } \\
\text { Measure }\end{array}$} & \multicolumn{4}{|c|}{ Monitoring } & \multirow{2}{*}{$\begin{array}{l}\text { Corrective } \\
\text { Actions }\end{array}$} & \multirow{2}{*}{$\begin{array}{l}\text { Verification } \\
\text { Activities }\end{array}$} & \multirow{2}{*}{$\begin{array}{l}\text { Record- } \\
\text { Keeping } \\
\text { Procedures }\end{array}$} \\
\hline & & & What & How & Frequency & Who & & & \\
\hline $\begin{array}{l}\text { CCP \#1- } \\
\text { HTST } \\
\text { Pasteurizer }\end{array}$ & $\begin{array}{l}\text { vegetative } \\
\text { pathogens }\end{array}$ & & & & & & & & \\
\hline & & & & & & & & & \\
\hline & & & & & & & & & \\
\hline & & & & & & & & & \\
\hline & & & & & & & & & \\
\hline & & & & & & & & & \\
\hline & & & & & & & & & \\
\hline
\end{tabular}

${ }^{1}$ See pathogens listed in Hazard Analysis 